\title{
Comparison of wheat-based rotation systems and monocropping systems under dryland Mediterranean conditions
}

\author{
Servet Tekin $^{1 *}$, Attila Yazar $^{2}$, Hatun Barut ${ }^{3}$ \\ (1. Department of Biosystems Engineering, Faculty of Agriculture, Kahramanmaras Sütcü İmam University, Kahramanmaras 46100, Turkey; \\ 2. Irrigation and Agricultural Structures Department, Çukurova University, Adana 01330 Turkey; \\ 3. Eastern Mediterranean Agricultural Research Institute, Adana 01370, Turkey)
}

\begin{abstract}
Mono-cropping systems consisting of general low-yielding cereals are crucial productivity constraints in dry areas of the Mediterranean region. A crop rotation consisting of quinoa (Chenopodium quinoa Willd.)-wheat (Triticum aestivum L)-chickpea (Cicer arietinum) was compared with monocropping in the Mediterranean region of Turkey. A four year crop rotation trial was set up in Adana, Turkey. A total of nine crop rotation systems of Quinoa (Q), chickpea (L) and wheat (W) were considered in this study. The four year results revealed that there was significant difference in grain and biomass yields, but no significant difference in plant height, harvest index, and 1000 grain weight of wheat among the treatments in crop rotation except number of grains per spike and soil organic matter. Continuous wheat and chickpea-wheat-chickpea-wheat (LWLW) produced significantly greater grain yield in 2010/2011 and 2011/2012. QWLW and QWQW rotation produced significantly lower biomass yield in 2008/2009. The maximum biomass yield of LWLW rotation resulted in 2011/2012 growing season. Therefore, the effect of previous crop on wheat grain and biomass yield in the four years of the rotation study was significantly different. In the long run, the favorable effects of legume-based rotations on crop yields and water productivity are apparent.
\end{abstract}

Keywords: crop rotation system, monocropping system, quinoa, Chenopodium quinoa, chickpea, dryland, yield DOI: $10.25165 / \mathrm{j}$.jjabe.20171005.3443

Citation: Tekin S, Yazar A, Barut H. Comparison of wheat-based rotation systems and monocropping systems under dryland Mediterranean conditions. Int J Agric \& Biol Eng, 2017; 10(5): 203-213.

\section{Introduction}

Mono-cropping cereal systems could reduce productivity in dry areas of the Mediterranean region. These systems are affected by multiple abiotic stresses, further aggravated by climate changes. Wheat-based monoculture (cultivation of wheat after wheat) is

Received date: 2017-04-22 Accepted date: 2017-08-28

Biographies: Attila Yazar, $\mathrm{PhD}$, Professor, research interests: irrigation, agricultural water management, Email: yazarat@ cu.edu.tr; Hatun Barut, $\mathrm{PhD}$, research interests: plant nutrition, soil science and agronomy, Email: baruthatun@yahoo.com.

*Corresponding author: Servet Tekin, Assistant Professor, research interests: irrigation, waste and salinity management, Department of Biosystems Engineering, Kahramanmaras Sütcü İmam University, Kahramanmaras 46100, Turkey. Tel: +90-344-3002082, Fax: +90-344-3002002, Email: servettekin@ ksu.edu.tr. common in several parts of the Mediterranean region countries such as Morocco, Syria and Turkey. It is important to renewal mono-cropping systems in these countries by improving other crops such as grain legumes and new crops in the wheat-based mono-cropping systems $^{[1,2]}$.

Because of the issue of increasing productivity under land-use pressure hinge around the issue of sustainability, involving the long-term perspective of the cropping system is considered. Given the inter-annual climatic variability in Mediterranean regions ${ }^{[3]}$, the only feasible way in which to evaluate the crop, soil and management variables in cropping systems is through long-term rotation trials ${ }^{[4]}$, in recognition of the synergism that exists between successive crops or sequence of crops ${ }^{[5]}$.

Instead of cereal monoculture, incorporating legumes in rotation systems has long been proven to enhance crop 
yields and environmental benefits. The adoption of cereal legume rotation to increase sustainable yield has also been studied in dry regions of the Mediterranean $\operatorname{basin}^{[2]}$. The main conclusions of these studies indicated the importance of legume in increasing soil $\mathrm{N}$ availability for the subsequent cereal due to the transfer of biologically fixed $\mathrm{N}$, to the $\mathrm{N}$-sparing effects of the legume, and to less immobilization of nitrate during the decomposition of legume residues ${ }^{[7]}$. Moreover, legumes, such as lentils and vetch, were shown to not deplete soil moisture to the same extent as a cereal crop, leaving some residual soil moisture for the succeeding crop in the rotation ${ }^{[1,8]}$. Legumes also contribute to pest and disease control of subsequent cereals in rotations ${ }^{[9]}$.

Normally, wheat crop has high yield in rotation system. The quantifying yield increase and the factors explaining that affect the increase will assist farmers to decide on crop sequences. Angus et al. ${ }^{[10]}$ reviewed and evaluated the yield increase, based on comparisons of wheat growing with yield $>900 \mathrm{~kg} / \mathrm{hm}^{2}$ after a break crop with wheat after wheat. The mean increase in wheat yield varied with species of break crop, ranging from $0.5 \mathrm{t} / \mathrm{hm}^{2}$ after oats to $1.2 \mathrm{t} / \mathrm{hm}^{2}$ after grain legumes. Based on overlapping experiments, the observed ranking of break-crop species in terms of mean yield response of the following wheat crop was: oats $<$ canola $\approx$ mustard $\approx$ flax $<$ field peas $\approx$ faba beans $\approx$ chickpeas $\approx$ lentils $\approx$ lupins. The mean additional wheat yield after oats or oilseed break crops was independent of the yield level of the following wheat crop. The wheat yield response to legume break crops was not clearly independent of yield level and was relatively greater at high yields.

Research conducted in some parts of the Mediterranean region has demonstrated the low efficiency of long-fallowing to increase cereal crop yields on an annual basis ${ }^{[11-13]}$. At the same time, the instability of monocultures has been well documented because of the effects on nutrient depletion ${ }^{[6]}$, increased weed and pest problems ${ }^{[14,15]}$, and low water use efficiency (WUE) ${ }^{[1]}$. Likewise, the grain yields under cereal monoculture was lower than under rotation which have been reported under Mediterranean semiarid conditions $^{[16]}$. The use of alternative crops such as legumes or cruciferous crops in the rotations has been reported to have beneficial effects not only on the overall yield of the rotation, but also in the chemical and physical properties of the soils ${ }^{[17,18]}$. However, in Mediterranean semiarid areas, the success of an alternative crop in a rotation are determined by its adaptability to drought stress situations, and its pattern and efficiency to the use of water ${ }^{[1]}$, the biotic stresses, and finally by its relative economic return to the farmer ${ }^{[19]}$.

The objective of this study was to evaluate the relative effects of a new crop quinoa and chickpea in wheat-based crop rotations under the semiarid Mediterranean climatic conditions. The crop rotations of improved varieties of legumes and new crops used as break crops were tested, as an alternative to monoculture. The hypothesis is that the traditional farming systems may be improved by including crop rotations, incorporating best species for the purpose and improved varieties.

\section{Materials and methods}

\subsection{Experimental site and soil}

A four year crop rotation experiment was set up on the Hacıali Farm of Çukurova Agricultural Research Institute $\left(36^{\circ} 48^{\prime} \mathrm{N}\right.$ and $\left.35^{\circ} 17^{\prime} \mathrm{E}, 7 \mathrm{~m} \mathrm{msl}\right)$, in Adana, Turkey from 2008/2009 to 2011/2012.

Typical Mediterranean climate prevails in the experimental area. Mean annual rainfall is $650 \mathrm{~mm}$, and about $65 \%$ of total falls during the winter months. The soil at the site is fine textured, varying from upper to lower layer. The soil is calcareous throughout the profile, and low in organic matter (about 1\%). Water table depth is several meters below the soil surface in the area. Some physical and chemical properties of the experimental soil are given in Tables 1 and 2 .

\subsection{Experimental design and treatments}

Nine rotations were established and maintained over 4 year period. Crop rotation treatments considered in the study are given in Table 3. In all, nine cropping sequences reflected the range of cereal-based rotations including legume (chickpea) and new crop quinoa (Chenopodium quinoa Willd.). Wheat monoculture was 
also included. Both monoculture and crop rotations were continued each year. The experimental design was randomized block design with four replications. Experimental plots were $5 \mathrm{~m}$ long and $3 \mathrm{~m}$ wide.

Table 1 Some physical properties of experimental soil

\begin{tabular}{|c|c|c|c|c|c|c|c|c|}
\hline Soil depth/cm & Sand $/ \%$ & Silt $/ \%$ & Clay $/ \%$ & Soil texture & $\begin{array}{c}\text { Bulk } \\
\text { density } / \mathrm{g} \cdot \mathrm{cm}^{-3}\end{array}$ & $\begin{array}{c}\text { Field } \\
\text { capacity } / g \cdot g^{-1}\end{array}$ & $\begin{array}{l}\text { Wilting } \\
\text { point } / g \cdot g^{-1}\end{array}$ & $\begin{array}{c}\text { Saturation soil } \\
\text { water content } / \%\end{array}$ \\
\hline $0-30$ & 16.1 & 39.6 & 44.3 & ${ }^{*} \mathrm{SiC}$ & 1.28 & 30.33 & 16.77 & 65 \\
\hline $30-60$ & 10.5 & 48.0 & 41.5 & $\mathrm{SiC}$ & 1.24 & 30.61 & 16.23 & 61 \\
\hline $60-90$ & 10.8 & 55.2 & 34.0 & ${ }^{* *} \mathrm{SiCL}$ & 1.26 & 29.90 & 14.21 & 66 \\
\hline $90-120$ & 35.7 & 42.1 & 22.2 & ${ }^{* * *} \mathrm{~L}$ & 1.34 & 21.64 & 10.65 & 52 \\
\hline
\end{tabular}

Note: ${ }^{*}$ SiC: Silty-clay; ${ }^{* *}$ SiCL: Silty-clay-loam; ${ }^{* * *}$ L: Loam.

Table 2 Chemical properties of experimental soil

\begin{tabular}{|c|c|c|c|c|c|c|c|}
\hline \multirow{2}{*}{ Soil depth/cm } & \multirow{2}{*}{$\mathrm{ECe} / \mathrm{dS} \cdot \mathrm{m}^{-1}$} & \multirow{2}{*}{ Total salt $/ \%$} & \multicolumn{2}{|c|}{ Plant available } & \multirow{2}{*}{ Organic matter/\% } & \multirow{2}{*}{ Total N/\% } & \multirow{2}{*}{ Organic carbon } \\
\hline & & & $\mathrm{P}_{2} \mathrm{O}_{5}$ & $\mathrm{~K}_{2} \mathrm{O}$ & & & \\
\hline $0-30$ & 1.33 & 0.055 & 3.10 & 123.18 & 1.65 & 0.08 & 0.96 \\
\hline $30-60$ & 1.12 & 0.044 & 0.23 & 38.51 & 0.64 & 0.03 & 0.37 \\
\hline $60-90$ & 1.21 & 0.051 & 0.31 & 38.51 & 0.49 & 0.02 & 0.28 \\
\hline $90-120$ & 1.18 & 0.039 & 0.39 & 40.74 & 0.31 & 0.02 & 0.18 \\
\hline
\end{tabular}

Table 3 Layout of the crop rotation experiment

\begin{tabular}{|c|c|c|c|c|c|c|}
\hline & Y0 & Y1 & Y2 & $\mathrm{Y} 3$ & Y4 & \\
\hline $\mathrm{T} 1$ & Wheat & Wheat & Wheat & Wheat & Wheat & a \\
\hline $\mathrm{T} 2 \mathrm{a}$ & Wheat & Legume & Wheat & New crop & Wheat & \\
\hline $\mathrm{T} 2 \mathrm{~b}$ & Wheat & Wheat & Legume & Wheat & New crop & $\mathrm{b}$ \\
\hline T3a & Wheat & New crop & Wheat & Legume & Wheat & \\
\hline $\mathrm{T} 3 \mathrm{~b}$ & Wheat & Wheat & New crop & Wheat & Legume & $\mathrm{c}$ \\
\hline $\mathrm{T} 4 \mathrm{~b}$ & Wheat & Wheat & Legume & Wheat & Legume & d \\
\hline T5a & Wheat & New crop & Wheat & New crop & Wheat & \\
\hline $\mathrm{T} 5 \mathrm{~b}$ & Wheat & Wheat & New crop & Wheat & New crop & $\mathrm{e}$ \\
\hline
\end{tabular}

Note: Y0: Years, the season prior to the trials; Y1: season 2008-2009; Y2: season 2009-2010; Y3: season 2010-2011; Y4: season 2011-2012. a: WWWW; b: WLWQ; c: QWLW; d: WLWL; e: WQWQ (W: Wheat; L: Legume; Q: Quinoa as new crop).

\subsection{Agronomic practices}

Agronomic practices such as planting and harvest dates, fertilizer applications, row spacing and seeding rate for the crops considered in the study are summarized in Table 4. In the crop rotation, a local bread wheat variety Karatopak was planted with a planter. Quinoa (Chenopodium quinoa Willd.) variety puno was sown by hand. Plants were thinned to a distance of $15 \mathrm{~cm}$ in the row. A total of 8 plots were sown with quinoa. A local chick pea variety inci was planted at $45 \mathrm{~cm}$ row spacing and $6 \mathrm{~cm}$ in the row with a four row planter. Plots were 6 rows wide and $5 \mathrm{~m}$ long with four replications. At planting $30 \mathrm{~kg} / \mathrm{hm}^{2} \mathrm{~N}$ as ammonium nitrate $(26 \% \mathrm{~N})$ and $50-60 \mathrm{~kg} / \mathrm{hm}^{2} \mathrm{P}_{2} \mathrm{O}_{5}$ in the form of triple super phosphate was applied broadcast and incorporated into the soil.

\subsection{Measurements and observations}

Soil samples were collected after harvest of crops in rotation treatments in 2008 to 2012. Soil samples in each plot were collected at $0-0.10 \mathrm{~m}$, and $0.10-0.20 \mathrm{~m}$ depths using an auger. The samples were mixed and sieved through $2 \mathrm{~mm}$ sieve before soil analysis. $\mathrm{Ca}, \mathrm{Mg}$, $\mathrm{K}$ and $\mathrm{P}$ were extracted using an ion-exchange resin. Extractable $\mathrm{Ca}, \mathrm{Mg}$ and $\mathrm{K}$ were determined with an atomic absorption spectrophotometer (AAS). Zn, Mn, $\mathrm{Cu}, \mathrm{Fe}$ were determined by AAS. Phosphorus was determined by a colorimetric method. Organic matter (OM) was determined by oxidizing $1 \mathrm{~cm}^{3}$ of soil with a $4 \mathrm{~N}$ sodium dichromate solution and $10 \mathrm{~N} \mathrm{H}_{2} \mathrm{SO}_{4}$. The amount of $\mathrm{OM}$ was evaluated by colorimetry and the results were obtained from a standard curve of a series of soils in which OM was determined by Walkley and Black 
method. Soil $\mathrm{pH}$ was determined in soil saturation extract. All plots were sampled to a depth of $0-20 \mathrm{~cm}$ and analyzed for total $\mathrm{N}$ (Kjeldahl). All these methods are described in Raij et al. ${ }^{[20]}$

Table 4 Agronomic practices, planting and harvest dates, and fertilizer applied in the crop rotation in the experimental years

\begin{tabular}{|c|c|c|c|c|c|c|}
\hline \multirow{2}{*}{$\begin{array}{l}\text { Agronomic } \\
\text { Practice }\end{array}$} & \multicolumn{2}{|c|}{ Wheat } & \multicolumn{2}{|c|}{ Chickpea } & \multicolumn{2}{|c|}{ Quinoa } \\
\hline & Planting & Harvest & Planting & Harvest & Planting & Harvest \\
\hline $2008 / 2009$ & Nov. 12 & June 7 & Dec. 12 & July 7 & March 12 & July 15 \\
\hline $2009 / 2010$ & Nov. 26 & June 2 & Dec. 10 & July 12 & March 11 & July 12 \\
\hline $2010 / 2011$ & Nov. 16 & June 5 & Dec. 8 & July 4 & March 29 & July 20 \\
\hline $2011 / 2012$ & Oct. 26 & June 3 & Dec. 12 & July 12 & Feb. 19 & July 19 \\
\hline Fertilizer & \multicolumn{2}{|c|}{$\begin{array}{c}60 \mathrm{~kg} \cdot \mathrm{hm}^{-2} \mathrm{~N} \text { at planting composite fertilizer } \\
(20 \%-20 \%-0) \mathrm{N}-\mathrm{P}-\mathrm{K} ; \mathrm{kg} \cdot \mathrm{hm}^{-2} \mathrm{~N} \text { at jointing in } \\
\text { the form of urea }(46 \% \mathrm{~N})\end{array}$} & \multicolumn{2}{|c|}{$\begin{array}{c}50 \mathrm{~kg} \cdot \mathrm{hm}^{-2} \mathrm{~N} \text { at planting composite fertilizer } \\
(20 \%-20 \%-0) \mathrm{N}-\mathrm{P}-\mathrm{K} ; \mathrm{kg} \cdot \mathrm{hm}^{-2} \mathrm{~N} \text { in the form of } \\
\text { urea at flowering stage }\end{array}$} & \multicolumn{2}{|c|}{$\begin{array}{c}30 \mathrm{~kg} \cdot \mathrm{hm}^{-2} \mathrm{~N} \text { and } 50-60 \mathrm{~kg} \cdot \mathrm{hm}^{-2} \mathrm{P}_{2} \mathrm{O}_{5} \text { at } \\
\text { planting (ammonium nitrate }(26 \% \mathrm{~N} \text { and triple } \\
\text { super phosphate) })\end{array}$} \\
\hline Row space & \multicolumn{2}{|c|}{$17.5 \mathrm{~cm}$} & \multicolumn{2}{|c|}{$45 \mathrm{~cm}$} & \multicolumn{2}{|c|}{$45 \mathrm{~cm}$} \\
\hline Seeding rate & \multicolumn{2}{|c|}{450 seeds per $\mathrm{m}^{2}$} & \multicolumn{2}{|c|}{$6 \mathrm{~cm}$ in the row } & \multicolumn{2}{|c|}{$15 \mathrm{~cm}$ in the row } \\
\hline Variety & \multicolumn{2}{|c|}{ Karatopak } & \multicolumn{2}{|c|}{ Inci } & \multicolumn{2}{|c|}{ Puno } \\
\hline
\end{tabular}

Soil water was measured with profile probe (Delta-T Devices PR2/6 model, Cambridge, UK) at two-week intervals in the plots. For this purpose, access tubes were installed at the center of each plot. The profile probe used in the study is measures soil water at 6 depths $(10 \mathrm{~cm}, 20 \mathrm{~cm}, 30 \mathrm{~cm} .40 \mathrm{~cm}, 60 \mathrm{~cm}$ and $100 \mathrm{~cm})$ down to $100 \mathrm{~cm}$. Evapotranspiration (ET) was calculated with the water balance equation (Equation (1)).

$$
E T=I+P \pm \Delta S W-D p-\text { Roff }
$$

where, $E T$ is evapotranspiration, $\mathrm{mm}$; $I$ is irrigation water applied, $\mathrm{mm} ; P$ is precipitation, $\mathrm{mm} ; \Delta S W$ changes in the water storage, $\mathrm{mm} ; D p$ is the deep percolation, $\mathrm{mm}$, and Roff is runoff, mm. If the rainfall amount exceeded the soil water storage prior to rainfall, the surplus was assumed to be deep percolation ${ }^{[21]}$.

Water productivity (WP) was calculated for individual crop as seed yield $(\mathrm{Y})$ which divided by seasonal crop evapotranspiration $(\mathrm{ET})^{[22]}$.

Biomass samples were collected at two weeks intervals, leaf area and leaf area index (LAI) was measured. Wheat plants in the $25 \mathrm{~cm}$ to $50 \mathrm{~cm}$ long row sections were cut above the ground level, then leaf area was measured with an optical leaf area meter (Li-Cor-3100, Lincoln, NE, USA), and the samples were dried in drying oven at $70^{\circ} \mathrm{C}$ for $2 \mathrm{~d}$ in order to calculate the above ground biomass yield (DM) at two weeks intervals.

\subsection{Statistical Analysis}

Data were analyzed with a randomized complete block model using the MSTAT-C (MSTAT-C is a computer based statistical software packages developed by the Crop and Soil Sciences Department of Michigan State University, USA). Treatment means were compared using Fisher's least significant difference (LSD) test at $p=0.05$.

\section{Results and discussion}

Monthly rainfalls during experimental years and long-term historical means (1965-2012) on Haciali Farm are shown in Figure 1. The 2009 growing season was wet following several dry years. However, 2010 season was relatively drier as compared to previous year. The 2011 wheat growing season was relatively wet year as compared to 2010.

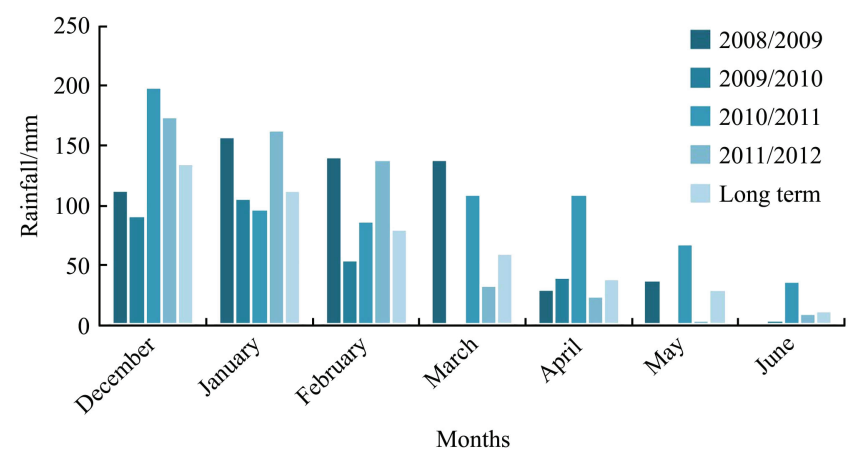

Figure 1 Monthly rainfall data of the experimental years of the crop rotation study on the Haciali Farm

Biomass yield, grain yield, harvest index (HI), 1000 seed weight, plant height, and number of spikes per $\mathrm{m}^{2}$ values in the crop rotation treatments in the experimental years are given in Table 5 . 
Table 5 Summary of the crop rotation study (wheat) results in the experimental years

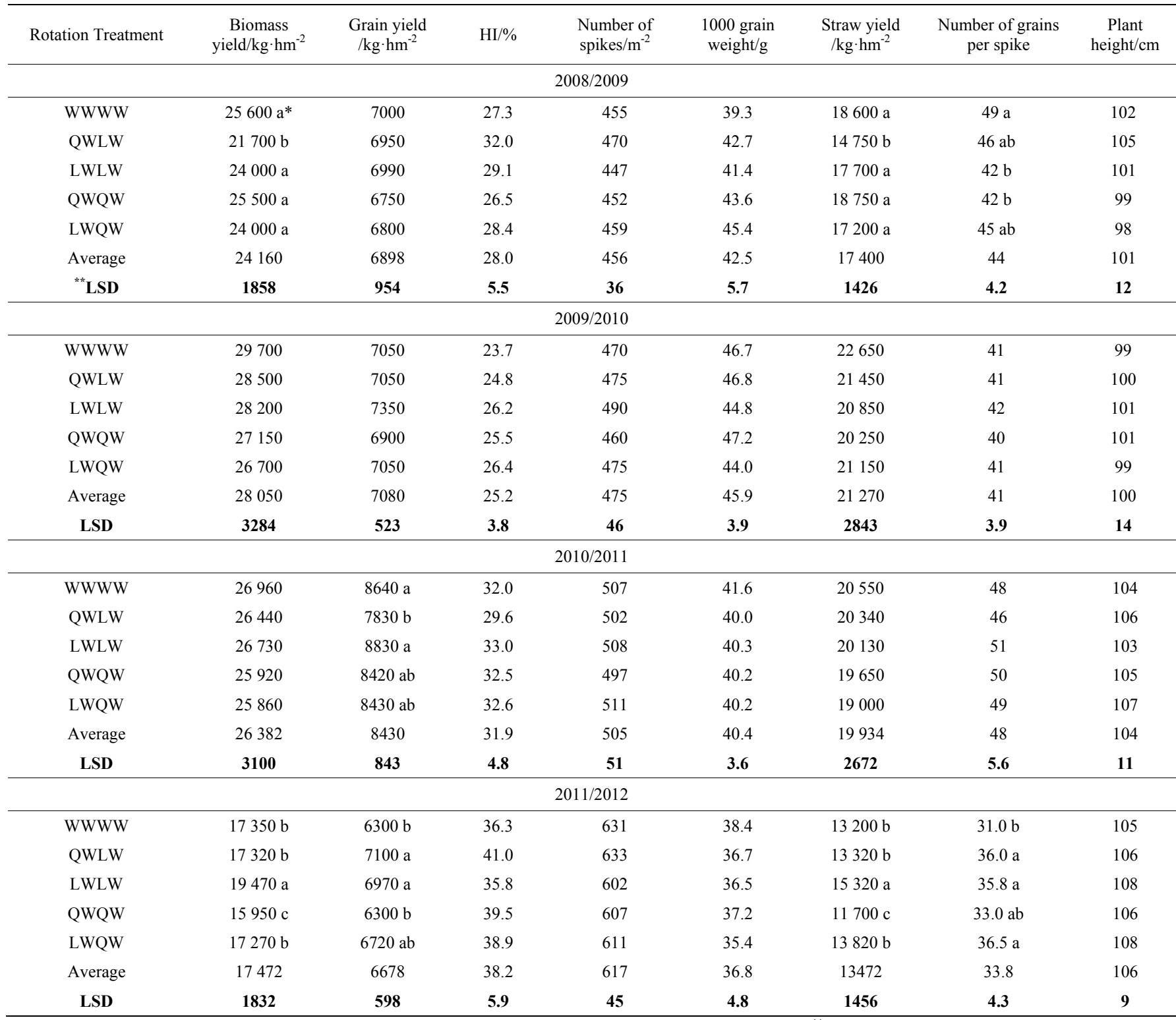

Note: *Any two values within a column are significantly different at the $5 \%$ level if they have no letters in common; ${ }^{* *}$ LSD: Least Significant Difference.

There was significant difference above ground biomass yields of wheat among the rotation treatments in 2008/2009 and 2011/2012 growing seasons. Average wheat biomass yields in crop rotation study varied from $24160 \mathrm{~kg} / \mathrm{hm}^{2}$ in $2008 / 2009$ to $28050 \mathrm{~kg} / \mathrm{hm}^{2}$ in 2009/2010 growing seasons. The least biomass of QWLW rotation was in in 2008/2009; and the greatest biomass of LWLW crop rotation produced in 2011/2012. The other years, crop rotations performed similarly. There were significant differences among the crop rotation treatments with respect to grain yields. Continuous wheat and chickpea-wheat-chickpea-wheat (LWLW) produced significantly greater grain yield in 2010/2011; LWLW and QWLW resulted in significantly greater grain yield in 2011/2012. However, the yields fluctuated among the years due to differences in rainfall and other climatic parameters such as air temperature, relative humidity and wind speed. Average wheat grain yields varied from $6300 \mathrm{~kg} / \mathrm{hm}^{2}$ to $7000 \mathrm{~kg} / \mathrm{hm}^{2}$ in the $2008 / 2009,6900 \mathrm{~kg} / \mathrm{hm}^{2}$ to $7080 \mathrm{~kg} / \mathrm{hm}^{2}$ in $2009 / 2010,7830 \mathrm{~kg} / \mathrm{hm}^{2}$ to $8640 \mathrm{~kg} / \mathrm{hm}^{2}$ in $2010 / 2011$, and $6070 \mathrm{~kg} / \mathrm{hm}^{2}$ to $7100 \mathrm{~kg} / \mathrm{hm}^{2}$ in 2011/2012 growing season. Overall, it become evident that legume-based rotations favorably affected crop yields and water productivity.

There was no significant difference in HI, 1000 seed weight, number of grains per spike and plant height values among the crop rotations. Crop rotation treatments tended to perform similarly in many aspects as continuous wheat in the experimental years in general. 
Average harvest index for wheat changed between $26.5 \%$ to $32.0 \%$ in $2008 / 2009 ; 23.7 \%$ to $26.4 \%$ in $2009 / 2010$; $29.6 \%$ to $33.0 \%$ in $2010 / 2011$; and $35.8 \%$ to $41.0 \%$ in 2011/2012. HI values were significantly greater in 2011/2012 growing season than previous years. Average 1000 seed weight varied from $39.3 \mathrm{~g}$ to $45.4 \mathrm{~g}$ in $2008 / 2009 ; 44.0 \mathrm{~g}$ to $47.2 \mathrm{~g}$ in $2009 / 2010 ; 40.0 \mathrm{~g}$ to $41.5 \mathrm{~g}$ in 2010/2011; and $35.4 \mathrm{~g}$ to $38.4 \mathrm{~g}$ in 2011/2012. 1000 grain weight values fluctuated among the years, and the highest values were attained in 2009/2010 season.

Average plant height values varied from $100 \mathrm{~cm}$ to $106 \mathrm{~cm}$ in the experimental years, and crop rotation treatments resulted in similar plant height values. Number of grains per spike was found to be significantly different among the crop rotation treatments in 2008/2009 and 2011/2012 growing seasons. The greatest grains per spike was WWWW treatment in 2008/2009; and the highest grain numbers per spike of LWLW and QWLW rotations produced in 2011/2012.

Rainfed semiarid Mediterranean agroecosystems are characterized by a low and erratic rainfall pattern during the growing season. In these systems, water content is the most limiting factor to crop development and yield. Thus, in our study, differences in aboveground biomass and grain yield between growing seasons were the result of the typical rainfall variability of these Mediterranean areas. When measuring the effect of previous crop on wheat yield and yield components in the crop rotation study, there was significant difference in grain yield, and biomass yields among the rotation treatments but no significant differences in plant height, harvest index, 1000 grain weight. The biomass yield of quinoa-wheat-chickpea-wheat and quinoa-wheat-quinoawheat rotation produced significantly lower than other rotation treatments in 2008/2009. The maximum biomass yield for chickpea-wheat-chickpea-wheat rotation resulted in in 2011/2012 growing season. Therefore, the effect of previous crop on wheat grain and biomass yields was significant different, but most of the yield components in the four years of the rotation study were not significantly different. Crop yields and water productivity were favored by the long term use of legume-based rotations.
Developments of LAI of wheat with time in crop rotation in the experimental years are depicted in Figure 2. LAI increased until flowering stage, then LAI decreased towards the physiological maturity. The maximum LAI value of 6.4 was observed during the 2008/2009 growing season in early April. In the second and third years, the maximum LAI of 4.8 was measured on April 4, 2010 and March 23, 2011. The reason for the difference between the LAI in the experimental years are due to rainfall distribution differences. There was no significant difference in LAI values among the wheat plots in rotation study. However, LAI differed among the years due to rainfall and other weather conditions.

Chickpea yield and yield components in crop rotation in the experimental years are summarized in Table 6 . There was no significant difference in chickpea yields between the crop rotation treatments. However, the yields significantly differed among the years.

Chickpea yields in the crop rotation treatments varied between $4109-4159 \mathrm{~kg} / \mathrm{hm}^{2}$ in 2009, and 3064-3254 $\mathrm{kg} / \mathrm{hm}^{2}$ among the plots in $2010 ; 2314-2402 \mathrm{~kg} / \mathrm{hm}^{2}$ in 2011 , and $3250-3480 \mathrm{~kg} / \mathrm{hm}^{2}$ in 2012 .

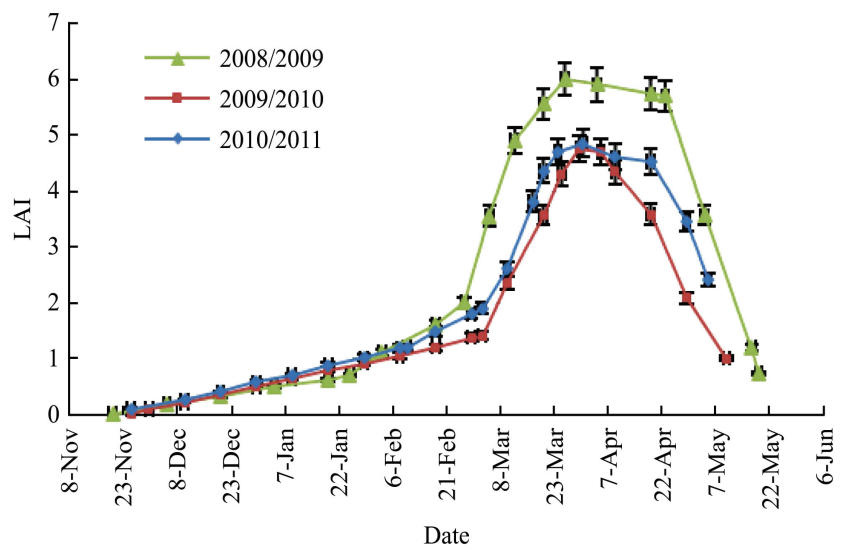

Figure 2 Development of wheat LAI with time in the experimental years

The fluctuation in seed yields among the years were due to rainfall received during the growing seasons and to occurrence of Ascochyta blight fungal disease especially in 2011. There was no significant difference among the crop rotation treatments in grain yields. Due to above normal rainfall received during the 2011 growing season Ascochyta Bligh fungal disease infected the chickpeas in crop rotation. The results revealed that the effect of previous crop on chickpea yield was not significant. 
Table 6 Chickpea yield and yield components in crop rotation experiment

\begin{tabular}{|c|c|c|c|c|c|c|c|c|c|}
\hline Treatment & $\begin{array}{c}\text { Plant height } \\
/ \mathrm{cm}\end{array}$ & $\begin{array}{l}1^{\text {st }} \text { pod height } \\
/ \mathrm{cm}\end{array}$ & $\begin{array}{c}\text { Main } \\
\text { branch number }\end{array}$ & $\begin{array}{c}\text { Pod } \\
/ \text { number }^{-p^{2}} \text { lant }^{-1}\end{array}$ & $\begin{array}{c}\text { Grain } \\
/ \text { number }^{-} \text {pod }^{-1}\end{array}$ & $\begin{array}{c}\text { Grain } \\
/ \text { number }^{-} \text {plant }^{-1}\end{array}$ & $\begin{array}{c}\text { Yield } \\
/ \mathrm{g} \cdot \text { plant }^{-1}\end{array}$ & $\begin{array}{l}100 \text { grain } \\
\text { weight/g }\end{array}$ & $\begin{array}{c}\text { Grain } \\
\text { yield } / \mathrm{kg} \cdot \mathrm{hm}^{-2}\end{array}$ \\
\hline \multicolumn{10}{|c|}{ 2008-2009 } \\
\hline WLWL & 80 & 34 & 3.0 & 136 & 1.5 & 176 & 68 & 40.0 & 4159 \\
\hline LSD & ns & ns & ns & $\mathrm{ns}$ & ns & ns & $\mathrm{ns}$ & ns & ns \\
\hline \multicolumn{10}{|c|}{ 2009-2010 } \\
\hline WQWL & 73 & 27 & $2.30 \mathrm{~b}^{*}$ & 126 & 1.2 & 232 & 62 & 36 & 3249 \\
\hline WLWL & 75 & 28 & $3.70 \mathrm{a}$ & 129 & 1.3 & 233 & 59 & 34 & 3062 \\
\hline LSD & ns & ns & 0.54 & $\mathrm{~ns}$ & ns & $\mathrm{ns}$ & $\mathrm{ns}$ & ns & ns \\
\hline \multicolumn{10}{|c|}{ 2010-2011 } \\
\hline WQWL & 83 & 37 & $2 b$ & $116 \mathrm{~b}$ & 1.0 & $167 \mathrm{a}$ & $30.9 \mathrm{~b}$ & 39 & 1860 \\
\hline WLWL & 85 & 43 & $3 \mathrm{a}$ & $170 \mathrm{a}$ & 1.2 & $147 \mathrm{~b}$ & $56.2 \mathrm{a}$ & 43 & 2162 \\
\hline \multicolumn{10}{|c|}{ 2011-2012 } \\
\hline WQWL & 78 & 30 & $3.3 \mathrm{~b}$ & $89.0 \mathrm{~b}$ & 2.3 & 240 & 57 & 36 & 3738 \\
\hline WLWL & 68 & 28 & $4.3 \mathrm{a}$ & $139.0 \mathrm{a}$ & 2.2 & 252 & 56 & 36 & 3667 \\
\hline LSD & $\mathrm{ns}$ & $\mathrm{ns}$ & 0.85 & 16.7 & ns & ns & ns & ns & ns \\
\hline
\end{tabular}

Note: Any two values within a column are significantly different at the $5 \%$ level if they have no letters in common.

Among the yield attributes, main branch numbers, grain numbers per plant, grain yield per plant were significantly different between the rotation treatments. WLWL produced greater values of these parameters than WQWL rotation. There were no significant differences in 1000 grain weight, plant height, first pod height and 100 seed weight values among the rotation treatments. However, these traits differed significantly among the experimental years. Plant height varied from $68 \mathrm{~cm}$ to $85 \mathrm{~cm}$ in the experimental years. Number of pods per plant changed from 87 to 139; number of grains per plant fluctuated between 98 to $252 ; 100$ seed weight values varied from $36 \mathrm{~g}$ to $43 \mathrm{~g}$. Maximum leaf area of chickpea was observed during the flowering and early pod formation growth stage as 2.9 (data is not provided). Then LAI started to decline towards the end of the growing season due to leaf senescence and yellowing of the leaves.

In the crop rotation experiment quinoa (Chenopodium quinoa Willd.) variety puno was grown under rain-fed conditions in 2009, 2011 and 2012 growing season due to wet year, and was grown under supplemental irrigation conditions in 2010. Drip irrigation laterals were placed between the plant rows in 2010. Quinoa was irrigated three times and a total of $225 \mathrm{~mm}$ of irrigation water was applied. Due to uneven plant stand in the plots, grain yields and yield components were determined on plant basis. The crop rotation treatments produced similar grain yields and yield components. However, the differences in yield and yield attributes were significantly different among the years. The rotation treatments did not have signifcant effect on yield attributes in general. Average quinoa grain yields changed between 1090 $\mathrm{kg} / \mathrm{hm}^{2}$ in 2009 to $2712 \mathrm{~kg} / \mathrm{hm}^{2}$ in 2010 under irrigation (Table 7). WLWQ resulted in significantly greater grain yield per plant than WQWQ plots in 2011 and 2012. Average grain yield per plant varied from $22.7 \mathrm{~g}$ to $45.7 \mathrm{~g}$; panicle weights varied from $43.0 \mathrm{~g}$ to $92.9 \mathrm{~g}$ per plant; 1000 seed weights varied between $1.85 \mathrm{~g}$ to $2.20 \mathrm{~g}$. Harvest index changed between $40.2 \%$ to $46.2 \%$. As indicated by the large variation in yield and other features among the quinoa plots in crop rotation study mainly caused by uneven plant establishment as well as the effect of previous crop. The results revealed that legumes involved as previous crop prior to quinoa production resulted in greater yield and biomass as compared to quinoa as previous crop in the crop rotation. Thus, legumes in the long run have positive effect on quinoa yield as well as irrigation in the Mediterranean region.

Crop water use (ET), yield (Y) and water productivity (WP) values for wheat, chickpea and quinoa under crop rotation in the experimental years are summarized in Table 8. Evapotranspiration of wheat estimated from the water balance equation varied from $425 \mathrm{~mm}$ in 
$2009 / 2010$ growing season to $670 \mathrm{~mm}$ in 2010/2011 growing season. Since wheat crop in the rotation produced under rain-fed conditions. ET values varied from year to year depending on the distribution and amount of rainfall during the growing season. Evapotranspiration of quinoa crop varied from $245 \mathrm{~mm}$ to $420 \mathrm{~mm}$ in the experimental years. The higher ET value of quinoa in 2010 was due to irrigation in this particular season. WP of wheat varied from $1.04 \mathrm{~kg} / \mathrm{m}^{3}$ to $1.67 \mathrm{~kg} / \mathrm{m}^{3}$ in the experimental years. The maximum
WP was obtained as $1.67 \mathrm{~kg} / \mathrm{m}^{3}$ in relatively drier year in 2009/2010. Chickpea water use varied between $456 \mathrm{~mm}$ to $605 \mathrm{~mm}$ in the experimental years. WP of chickpea were lower $\left(0.51-0.75 \mathrm{~kg} / \mathrm{m}^{3}\right)$ than wheat but greater than that those of quinoa $\left(0.39-0.63 \mathrm{~kg} / \mathrm{m}^{3}\right)$. Thus, the final yield and WP in these Mediterranean semiarid agro ecosystems depend not only on the total rainfall during the growing season but also on the pattern of rainfall during the growing season.

Table 7 Quinoa yields and yield components under various crop rotation treatments in the experimental years

\begin{tabular}{|c|c|c|c|c|c|c|c|c|}
\hline $\begin{array}{c}\text { Crop } \\
\text { Rotation }\end{array}$ & $\begin{array}{l}\text { Plant height } \\
/ \mathrm{cm}\end{array}$ & $\begin{array}{l}\text { Panicle weight } \\
\text { /g }\end{array}$ & $\begin{array}{l}\text { Biomass per } \\
\text { plant } / g\end{array}$ & $\begin{array}{l}\text { Grain yield per } \\
\text { plant } / g\end{array}$ & $\begin{array}{l}1000 \text { grain weight } \\
\text { /g }\end{array}$ & $\begin{array}{l}\text { Grain Yield } \\
/ \mathrm{kg} \cdot \mathrm{hm}^{-2}\end{array}$ & $\begin{array}{l}\text { Biomass yield } \\
\quad / \mathrm{kg} \cdot \mathrm{hm}^{-2}\end{array}$ & $\begin{array}{l}\mathrm{HI} \\
/ \%\end{array}$ \\
\hline \multicolumn{9}{|c|}{2009} \\
\hline WLWQ & 95 & 22.41 & 40.49 & 15.81 & 2.01 & 1096 & 2469 & 44.4 \\
\hline WQWQ & 91 & 23.36 & 45.98 & 15.89 & 2.10 & 1090 & 2466 & 44.2 \\
\hline LSD & 8 & 4.20 & 7.5 & 2.10 & 0.21 & 298 & 456 & 4.1 \\
\hline \multicolumn{9}{|c|}{2010} \\
\hline WLWQ & 102 & 65.99 & 92.88 & 36.40 & 1.96 & 2614 & 5901 & 44.3 \\
\hline WQWQ & 95 & 71.21 & 95.76 & 37.50 & 1.99 & 2712 & 5883 & 46.2 \\
\hline LSD & 8 & 9.20 & 10.50 & 7.10 & 0.16 & 367 & 629 & 4.1 \\
\hline \multicolumn{9}{|c|}{2011} \\
\hline WLWQ & 91.0 & 27.72 & 62.37 & $24.12 \mathrm{a}$ & 1.85 & $1443 \mathrm{a}$ & 3317 a & 43.5 \\
\hline WQWQ & 88.0 & 31.15 & 61.22 & $19.78 \mathrm{~b}$ & 1.94 & $1164 \mathrm{~b}$ & $2519 \mathrm{~b}$ & 46.2 \\
\hline LSD & 7.5 & 5.60 & 8.90 & 4.20 & 0.14 & 312 & 462 & 3.9 \\
\hline \multicolumn{9}{|c|}{2012} \\
\hline WLWQ & 89.0 & 24.32 & 47.59 & $20.42 \mathrm{a}$ & 1.92 & 1326 & 3298 & 40.2 \\
\hline WQWQ & 91.0 & 22.94 & 42.19 & $16.28 \mathrm{~b}$ & 1.89 & 1197 & 2843 & 42.1 \\
\hline LSD & 7.9 & 3.90 & 6.90 & 4.10 & 0.10 & 266 & 420 & 3.7 \\
\hline
\end{tabular}

Note: *Any two values within a column are significantly different at the $5 \%$ level if they have no letters in common.

Table 8 Crop water use (ET), yield ( $(Y)$, and water productivity (WP) values for wheat, chickpea and quinoa under crop rotation.

\begin{tabular}{|c|c|c|c|c|c|c|c|c|c|}
\hline \multirow{2}{*}{ Years } & \multicolumn{3}{|c|}{ Wheat } & \multicolumn{3}{|c|}{ Chickpea } & \multicolumn{3}{|c|}{ Quinoa } \\
\hline & $E T / \mathrm{mm}$ & $\mathrm{Y} / \mathrm{kg} \cdot \mathrm{hm}^{-2}$ & $W P / \mathrm{kg} \cdot \mathrm{m}^{-3}$ & $E T / \mathrm{mm}$ & $\mathrm{Y} / \mathrm{kg} \cdot \mathrm{hm}^{-2}$ & $W P / \mathrm{kg} \cdot \mathrm{m}^{-3}$ & $E T / \mathrm{mm}$ & $\mathrm{Y} / \mathrm{kg} \cdot \mathrm{hm}^{-2}$ & $W P / \mathrm{kg} \cdot \mathrm{m}^{-3}$ \\
\hline $2008 / 09$ & $625 \mathrm{a}$ & $6760 \mathrm{~b}$ & $1.08 \mathrm{c}$ & $570 \mathrm{a}$ & $4070 \mathrm{a}$ & $0.71 \mathrm{a}$ & $245 \mathrm{c}$ & $1310 \mathrm{~b}$ & $0.53 \mathrm{~b}$ \\
\hline $2009 / 10$ & $425 \mathrm{~b}$ & $7080 \mathrm{~b}$ & $1.67 \mathrm{a}$ & $465 \mathrm{~b}$ & $2357 \mathrm{~b}$ & $0.51 \mathrm{c}$ & $420 \mathrm{a}$ & $2657 \mathrm{a}$ & $0.63 \mathrm{a}$ \\
\hline $2010 / 11$ & $670 \mathrm{a}$ & 8430 a & $1.26 \mathrm{~b}$ & $605 \mathrm{a}$ & $3770 \mathrm{a}$ & $0.62 \mathrm{~b}$ & $340 \mathrm{~b}$ & $1321 \mathrm{~b}$ & $0.39 \mathrm{c}$ \\
\hline $2011 / 12$ & $585 \mathrm{ab}$ & $6070 \mathrm{c}$ & $1.04 \mathrm{c}$ & $552 \mathrm{ab}$ & $4120 \mathrm{a}$ & $0.75 \mathrm{a}$ & $195 \mathrm{~d}$ & $1326 \mathrm{~b}$ & $0.68 \mathrm{a}$ \\
\hline LSD & 91 & 990 & 0.21 & 76 & 730 & 0.10 & 49 & 986 & 0.11 \\
\hline
\end{tabular}

Note: *Any two values within a column are significantly different at the $5 \%$ level if they have no letters in common.

In order to evaluate the effect of the crop rotation treatments on soil productivity, some chemical and physical properties of the experimental soil at the beginning and at the end of the four-year study period, soil samples were taken in $0-10 \mathrm{~cm}$ and $10-20 \mathrm{~cm}$ soil depth in the experimental plots. The results of the soil analysis prior to crop rotation study are given in Tables 9 and 10 .
Soil physical and chemical properties were determined at two depths (0.00-0.10 m, and 0.10-0.20 m) in 2008 and 2012 in the crop rotation treatments. Results showed that, significantly higher amounts $(p<0.05)$ of OM, extractable $\mathrm{P}, \mathrm{K}$ and $\mathrm{N}$ occurred at the $0-0.01 \mathrm{~m}$ soil depth than in $0.10-0.20 \mathrm{~m}$ soil depth in all experimental plots. Four years later, the effects of the crop rotation treatments on the soil parameters considered were 
considerable. No significant variation in soil $\mathrm{pH}$ occurred among the treatments. Significant decline in extractable $\mathrm{Cu}, \mathrm{Zn}, \mathrm{Mn}, \mathrm{Fe}, \mathrm{K}$ and $\mathrm{P}$ occurred at the $0.1 \mathrm{~m}$ and $0.2 \mathrm{~m}$ depths in crop rotation treatments at the end of the study. Crop rotation factor did have evident influence in nutrients status in 2012 compared to 2008. Rotations significantly reduced $\mathrm{P}, \mathrm{K}$ and other microelements in the $0-20 \mathrm{~cm}$ soil depth compared to the soil conditions at the beginning of the study in 2008. N content in the soil increased in treatment plots allocated to legumes (chickpea) in comparison to continuous wheat and rotations with quinoa (Table 11). Cereal-legume rotation has extensively been studied in the dry regions of the Mediterranean basin ${ }^{[2]}$. The main conclusions of these studies indicated the importance of legume in increasing soil $\mathrm{N}$ availability for the subsequent cereal due to the transfer of biologically fixed $\mathrm{N}$, to the $\mathrm{N}$-sparing effects of the legume, and to less immobilization of nitrate during the decomposition of legume residues. The OM status at the two depths studied, which increased in all treatments over time, and OM tended to be higher in the rotation treatments with legumes than crop rotation treatments including quinoa (Table 11). These changes in soil chemical properties did not result in differences in wheat, chickpea and quinoa grain yields.

Table 9 Soil nutritional properties of the $0-10 \mathrm{~cm}$ and $10-20 \mathrm{~cm}$ soil layers at the beginning of study

\begin{tabular}{cccccc}
\hline Soil depth/cm & $\mathrm{CaCO}_{2}$ & Organic matter $/ \%$ & $\mathrm{pH}$ & $\mathrm{EC} / \mathrm{dS} \cdot \mathrm{m}^{-1}$ & Soil texture \\
\hline $0-10$ & 15.5 & $2.20 \pm 0.02$ & $7.20 \pm 0.01$ & $0.37 \pm 0.02$ & $\mathrm{SiC}$ \\
$10-20$ & 16.6 & $2.10 \pm 0.00$ & $7.20 \pm 0.03$ & $0.38 \pm 0.03$ & $\mathrm{SiC}$ \\
\hline
\end{tabular}

Table 10 Chemical properties of the $0-10 \mathrm{cn}$ and $10-20 \mathrm{~cm}$ soil layers at the beginning of the study

\begin{tabular}{cccccccc}
\hline Soil Depth/cm & $\mathrm{Cu}$ & $\mathrm{Mn}$ & $\mathrm{Fe}$ & $\mathrm{Zn}$ & $\mathrm{K}$ & $\mathrm{P}$ & $\mathrm{N}$ \\
\hline $0-10$ & $1.30 \pm 0.01$ & $10.30 \pm 1.68$ & $6.30 \pm 0.11$ & $0.40 \pm 0.06$ & $362.00 \pm 4.24$ & $32.83 \pm 4.15$ & $636.00 \pm 7.98$ \\
$10-20$ & $1.30 \pm 0.02$ & $11.50 \pm 3.06$ & $6.30 \pm 0.11$ & $0.30 \pm 0.00$ & $363.00 \pm 3.90$ & $14.67 \pm 1.86$ & $665.00 \pm 8.34$ \\
\hline
\end{tabular}

Table 11 Chemical properties of the $0-10$ and $10-20 \mathrm{~cm}$ soil layers at the end of the study

\begin{tabular}{|c|c|c|c|c|c|c|c|c|c|c|}
\hline \multirow{2}{*}{$\begin{array}{l}\text { Crop rotation } \\
\text { treatments }\end{array}$} & \multirow{2}{*}{ Soil depth/cm } & $\mathrm{K}$ & $\mathrm{Cu}$ & $\mathrm{Mn}$ & $\mathrm{Fe}$ & $\mathrm{Zn}$ & $\mathrm{P}$ & $\mathrm{N}$ & \multirow{2}{*}{$\mathrm{pH}$} & \multirow{2}{*}{$\mathrm{OM} / \%$} \\
\hline & & & & & $\mathrm{mg} \cdot \mathrm{kg}$ & & & & & \\
\hline \multirow{2}{*}{ WWWW } & $0-10$ & $256 \mathrm{a}$ & 1.26 & 1.63 & 0.50 & 0.15 & $6.49 \mathrm{~b}$ & $762 \mathrm{c}$ & 7.9 & $2.1 \mathrm{a}$ \\
\hline & $10-20$ & $229 \mathrm{dc}$ & 1.25 & 3.05 & 0.61 & 0.13 & $3.90 \mathrm{e}$ & $726 \mathrm{~cd}$ & 7.9 & $1.9 \mathrm{~b}$ \\
\hline \multirow{2}{*}{ LWQW } & $0-10$ & $217 d$ & 1.36 & 2.49 & 0.67 & 0.17 & $5.36 \mathrm{c}$ & $803 \mathrm{c}$ & 7.9 & $2.0 \mathrm{ab}$ \\
\hline & $10-20$ & $215 d$ & 1.34 & 3.31 & 0.65 & 0.13 & $1.63 \mathrm{~h}$ & $769 \mathrm{c}$ & 8.1 & $1.8 \mathrm{~b}$ \\
\hline \multirow{2}{*}{ WLWQ } & $0-10$ & $324 a$ & 1.35 & 4.40 & 0.56 & 0.17 & $7.93 \mathrm{a}$ & $786 c$ & 8.1 & $1.9 \mathrm{~b}$ \\
\hline & $10-20$ & $265 b$ & 1.19 & 2.99 & 0.47 & 0.29 & $3.05 \mathrm{f}$ & $752 \mathrm{c}$ & 7.9 & $1.8 \mathrm{~b}$ \\
\hline \multirow{2}{*}{ QWLW } & $0-10$ & $264 b$ & 1.50 & 3.61 & 0.75 & 0.16 & $6.16 \mathrm{~b}$ & $726 \mathrm{~cd}$ & 8.1 & $2.0 \mathrm{ab}$ \\
\hline & $10-20$ & $235 \mathrm{dc}$ & 1.26 & 5.57 & 0.57 & 0.16 & $2.49 \mathrm{~g}$ & $822 \mathrm{c}$ & 8.1 & $1.9 \mathrm{~b}$ \\
\hline \multirow{2}{*}{ WQWL } & $0-10$ & $237 \mathrm{dc}$ & 1.35 & 1.25 & 0.51 & 0.21 & $3.95 \mathrm{e}$ & $949 \mathrm{a}$ & 8.0 & $2.1 \mathrm{a}$ \\
\hline & $10-20$ & $229 \mathrm{dc}$ & 1.50 & 1.70 & 0.58 & 0.14 & $3.31 \mathrm{f}$ & $802 \mathrm{c}$ & 7.9 & $2.0 \mathrm{ab}$ \\
\hline \multirow{2}{*}{ LWLW } & $0-10$ & $284 b$ & 1.54 & 2.41 & 0.72 & 0.17 & $3.68 \mathrm{f}$ & $815 c$ & 8.1 & $2.2 \mathrm{a}$ \\
\hline & $10-20$ & $206 d$ & 1.35 & 1.31 & 0.61 & 0.19 & $4.40 \mathrm{~d}$ & $796 c$ & 7.9 & $2.0 \mathrm{ab}$ \\
\hline \multirow{2}{*}{ WLWL } & $0-10$ & $255 b$ & 1.54 & 1.82 & 0.79 & 0.14 & $4.89 \mathrm{~d}$ & $968 \mathrm{a}$ & 8.0 & $2.3 \mathrm{a}$ \\
\hline & $10-20$ & $231 \mathrm{dc}$ & 1.48 & 1.51 & 0.62 & 0.19 & $2.99 \mathrm{fg}$ & $897 b$ & 8.0 & $2.1 \mathrm{a}$ \\
\hline \multirow{2}{*}{ QWQW } & $0-10$ & $257 \mathrm{~b}$ & 1.44 & 1.26 & 0.65 & 0.19 & $7.12 \mathrm{a}$ & $703 \mathrm{~cd}$ & 8.0 & $1.9 \mathrm{~b}$ \\
\hline & $10-20$ & $241 b c$ & 1.38 & 1.51 & 0.62 & 0.14 & $3.61 \mathrm{f}$ & $652 d$ & 7.9 & $1.8 \mathrm{~b}$ \\
\hline \multirow{2}{*}{ WQWQ } & $0-10$ & $273 b$ & 1.31 & 1.66 & 0.58 & 0.19 & $5.42 \mathrm{c}$ & $725 \mathrm{~cd}$ & 8.0 & $1.8 \mathrm{~b}$ \\
\hline & $10-20$ & $254 \mathrm{~b}$ & 1.35 & 1.27 & 0.56 & 0.18 & $5.57 \mathrm{c}$ & $635 d$ & 8.0 & $1.7 \mathrm{bc}$ \\
\hline
\end{tabular}

Note: *Any two values within a column are significantly different at the $5 \%$ level if they have no letters in common.

With few exceptions, the soils of the Mediterranean region are low in organic matter and consequently in the reserves of total $\mathrm{N}$, thus posing a limit of growing crops without fertilizer $\mathrm{N}$ or biological $\mathrm{N}$ fixation through 
legumes. Dry-land crop responses to $\mathrm{N}$ varied widely throughout the region from $30 \mathrm{~kg} \mathrm{~N} / \mathrm{hm}^{2}$ to $150 \mathrm{~kg} \mathrm{~N} / \mathrm{hm}^{2}$, being dependent on soil $\mathrm{N}$ status and seasonal rainfall as the major determinant of yields. Fertilizer $\mathrm{N}$ use had a positive effect on grain quality with increased protein, as well as soil OM and thus soil quality ${ }^{[23]}$.

An economic evaluation was carried out in order to compare the net benefits from crop rotation treatments with monocrop wheat production in the mediterranean region. Total production costs for wheat, chikpea were obtained from the Regional Directorate of the Agricultural Ministry. Since quinoa production is not practiced commercially, we estimated the production costs for quinoa under rainfed conditions using the data obtained from the experimental work carried out in Adana. Total production costs of rainfed wheat and chickpea are given as $1653 \mathrm{TL} / \mathrm{hm}^{2}$ and $1463 \mathrm{TL} / \mathrm{hm}^{2}$, respectively (in $20121 \$=1.89 \mathrm{TL}$ ). Rainfed quinoa production cost was estimated as $1324 \mathrm{TL} / \mathrm{hm}^{2}$. Unit prices for wheat and chickpea are given as $0.75 \mathrm{TL} / / \mathrm{hm}^{2}$ and $2.03 \mathrm{TL} / \mathrm{hm}^{2}$ in Turkish market. There is no price establihed for quinoa in the market yet in Turkey. However, imported quinoa prices varies from $12 \mathrm{TL} / \mathrm{kg}$ to $20 \mathrm{TL} / \mathrm{kg}$ (\$4.85/kg in Bolivia; which is equivalent to $8.7 \mathrm{TL} / \mathrm{kg}$ ). We used $6 \mathrm{TL} / \mathrm{kg}$ for quinoa as price. Total gross income generated for wheat (average yield, $\left.7085 \mathrm{~kg} / \mathrm{hm}^{2}\right)$, chickpea $\left(3579 \mathrm{~kg} / \mathrm{hm}^{2}\right)$ and quinoa (1315 $\mathrm{kg} / \mathrm{hm}^{2}$ ) are estimated at $5315 \mathrm{TL} / \mathrm{hm}^{2}, 7265 \mathrm{TL} / \mathrm{hm}^{2}$, and $7890 \mathrm{TL} / \mathrm{hm}^{2}$. Thus, quinoa production results in a net benefit of $6566 \mathrm{TL} / \mathrm{hm}^{2}$, followed by chickpea and wheat. Thus, quinoa and chickpea growing is recommended in the area for greater net benefit as well as improving crop diversification for food security in the region.

\section{Conclusions}

Crop rotation with quinoa-wheat-chickpea was compared to monocropping in the Mediterranean region of Turkey, and the four-year results revealed the positive impact of crop rotation over monocropping on yield, and soil organic matter. The four year results revealed that there was no significant difference in biomass (dry matter) and grain yield, plant height, harvest index, number of grains per spike and 1000 grain weight of wheat among the treatments in crop rotation. The effect of previous crop on wheat yield and yield components in the four years of the rotation study was not significantly different. However, in the long-term favorable effect on legume-based rotations on crop yields and water-use efficiency is expected to be more apparent.

This study showed that food legumes can lead to a build-up of soil $\mathrm{N}$ mainly as organic forms in semi-arid soils, which can subsequently contribute to cereal nutrition following mineralization. Such nutrient accumulation is critical for maintenance of soil quality and sustainability of land use, especially in rainfed Mediterranean cropping environments.

The greatest limitation to growth was the supply of water and not the soil moisture storage potential. Wheat grain yield was dictated by the extent to which the alternative crops in the rotation dried out the soil profile, in addition to seasonal rainfall and its distribution. Chickpea and quinoa extracted as much water as continuous wheat. Wheat after these crops was solely dependent on current seasonal rainfall. Wheat-legume rotation systems with additional $\mathrm{N}$ input in the wheat phase not only can maintain sustainable production system, but also are more efficient in utilizing limited rainfall.

Mediterranean semiarid areas, the success of an alternative crop in a rotation are determined by its adaptability to drought stress situations, its pattern and efficiency to the use of water, the biotic stresses, and finally by its relative economic return to the farmer. Improved soil and crop management with efficient use of crop rotations will increase productivity and productive capacity of soils for the long term resulting in improved living standards of the small farmers, too. It will also help in sustaining productivity with improved water use efficiency as well as sustaining soil fertility.

\section{Acknowledgments}

The authors would like to thank the financial support of the EU project ref. KBBE-2008-212337 (SWUP-MED) Sustainable water use securing food production in dry areas of the Mediterranean region, which allowed carrying out these experiments. 


\section{[References]}

[1] Pala M, Ryan J, Zhang H, Singh M, Harris H C. Water-use efficiency of wheat-based rotation systems in a Mediterranean environment. Agricultural Water Management, 2007; 93: 136-144.

[2] Ryan J, Masri S, Ibrikçi H, Singh M, Pala M, Harris H C. Implications of cereal-based crop rotations, nitrogen fertilization, and stubble grazing on soil organic matter in a Mediterranean-type environment. Turkish Journal of Agriculture and Forestry, 2008; 32: 289-297.

[3] Kassam A H. Climate, soil and land resources in North Africa and West Asia. Soil Water and Nitrogen in Mediterranean-Type Environments, 1981; 1-29.

[4] Karlen D L, Varvel G E, Bullock D G, Curse R M. Crop rotations for the 21 st century. Advances in Agronomy, 1994; 53: 1-45.

[5] Anderson R L. Are some crops synergistic to following crops? Agronomy Journal, 2005; 97: 7-10.

[6] Campbell C A, Zentner R P, Basnyat P, Wang H, Selles F, McConkey B G, et al. Water use efficiency and water and nitrate distribution in soil in the semiarid prairie: Effect of crop type over 21 years. Canadian Journal of Plant Science, 2007; 87: 815-827.

[7] Chalk P M. Dynamics of biologically fixed $\mathrm{N}$ in legume-cereal rotations: a review. Australian Journal of Agricultural Research, 1998; 49(3): 303-316.

[8] Dalias P. Increased yield surplus of vetch-wheat rotations under drought in a mediterranean environment. The Scientific World Journal, 2012; Article ID 658518, 6 pages

[9] Zogg H. Crop rotation and biological soil desinfection. Qualitas Plantarum et Materiae Vegetabiles, 1969; 18(1-3): 256-273.

[10] Angus J F, Kirkegaard J A, Hunt J R, Ryan M H, Ohlander L, Peoples M B. Break crops and rotations for wheat. Crop and Pasture Science, 2015; 66(6): 523-552.

[11] Lopez M V, Arrue J L. Growth, yield and water use efficiency of winter barley in response to conservation tillage in a semi-arid region of Spain. Soil Tillage Research, 1997; 44: 35-54.

[12] Lampurlanes J, Angas P, Cantero-Martinez C. Tillage effects on water storage during fallow and on barley root growth and yield in two contrasting soils of the semi-arid
Segarra region in Spain. Soil Tillage Research, 2002; 65: 207-220.

[13] Moret D, Arrue J L, Lopez M V, Gracia R. Winter barley performance under different cropping and tillage systems in semiarid Aragon (NE Spain). European Journal of Agronomy, 2007; 26: 54-63.

[14] Liebman M, Dick E. Crop rotation and intercropping strategies for weed management. Ecological Application, 1993; 3: 92-122.

[15] Gurr G M, Wratten S D, Luna J M. Multi-function agricultural biodiversity: Pest management and other benefits. Basic Applied Ecology, 2003; 4: 107-116.

[16] Diaz-Ambrona C H, Minguez I. Cereal-legume rotations in a Mediterranean environment: Biomass and yield production. Field Crops Research, 2001; 70: 139-151.

[17] Hernanz J L, Lopez R, Navarrete L, Sanchez-Giron V Longterm effects of tillage systems and rotations on soil structural stability and organic carbon stratifi cation in semiarid central Spain. Soil Tillage Research, 2002; 66: 129-141.

[18] Álvaro-Fuentes J, Lampurlanés J, Cantero-Martínez C. Alternative crop rotations under mediterranean no-tillage conditions: Biomass, grain yield, and water-use efficiency. Agronomy Journal, 2009; 101: 1227-1233.

[19] Jacobsen S E, Jensen C R, Liu F. Improving crop production in the arid Mediterranean climate. Field Crops Research, 2012; 128: 34-47.

[20] Raij B, Quaggio J A, da Silva N M. Extraction of phosphorus, potassium, calcium and magnesium from soils by an ion-exchange resin procedure. Communications Soil Science and Plant Analysis, 1987; 17: 547-566.

[21] Sezen S M, Yazar A. Wheat yield response to line-source sprinkler irrigation in the arid Southeast Anatolia region of Turkey. Agricultural Water Management, 2006; 81: 59-76.

[22] Brauman K A, Siebert S, Foley J A. Improvements in crop water productivity increase water sustainability and food security-a global analysis. Environmental Research Letter, 2013; 8(2): 1-7.

[23] Ryan J, Ibrikci H, Sommer R, McNeill A. Nitrogen in rainfed and irrigated cropping systems in the Mediterranean region. Advances in Agronomy, 2009; 104: 53-136. 